\title{
Impact of Chemical Aging on the Fracture Resistance of Two Ceramic Materials: Zirconia-Reinforced Lithium Silicate and Lithium Disilicate Ceramics
}

\author{
Mohamed S. Mohamed ${ }^{1}$, Cherif A. Mohsen ${ }^{1}$, Hisham katamish ${ }^{2}$ \\ ${ }^{1}$ Department of Fixed Prosthodontics, Faculty of Dentistry, Minia University, Minia, Egypt; ${ }^{2}$ Department of Fixed Prosthodontics, \\ Faculty of Dentistry, Cairo University, Giza, Egypt
}

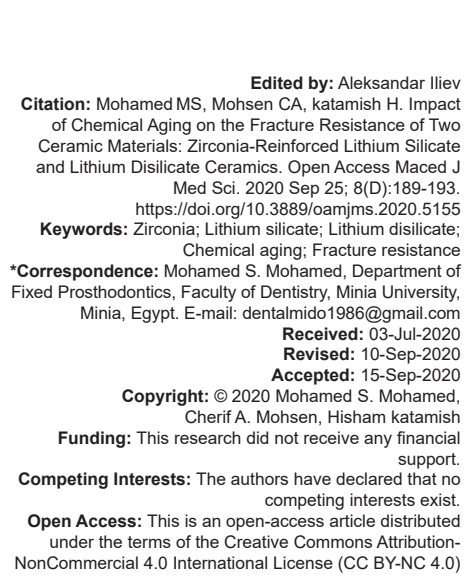

\section{Introduction}

In the past 10 years, zirconia and high-strength glass-ceramics (e.g., lithium disilicate) have become established in prosthodontics and restorative dentistry and are clinically used.

The primary reason for the development of zirconia-reinforced lithium silicate (ZLS) is that zirconia offers high strength of about $1000 \mathrm{MPa}$ and high strength glass ceramic in the range of $360 \mathrm{MPa}-400 \mathrm{MPa}$, to provide safely ceramic options for a wide range of indications. With the CAD/CAM technology and the full potential of these materials are covered.

The outstanding properties of ZLS are a function of its unique microstructure. The presence of $10 \%$ zirconia in the glass phase in atomically dissolved form provides high strength, safety, and long-lasting restorations. The zirconia is essentially responsible for the nucleation of the crystal phase.

The inclusion of $10 \%$ of zirconium oxide ensures particularly high strength. The crystallites formed are 4-8 times smaller than crystals of conventional lithium disilicate. The result is an ultra-fine microstructure that has high average flexural strength with high glass content. This has great effects on the optical and mechanical properties of the material.

In the chewing simulation, it behaves in a way that is atypical of ceramic materials while ceramics lose some of their strength in the aging process; it retains its high level of strength due to ample strength reserves.

The $70 \%$ crystal phase of the lithium disilicate glass-ceramic material refracts the light very naturally, while also providing better flexural strength (360-400 MPa). This gives more indications for use and the ability to place restorations using usual cementation techniques, while also having strength and esthetics [1].

Fracture resistance within a safety range should be required for a favorable clinical prognosis of all-ceramic [2]. The fracture behavior of the ceramics should be evaluated for the longevity and estimate the risk of failure [3], [4], [5], [6]. 


\section{Materials and Methods}

Crown shaped samples were constructed by CADICAM technology $(n=40)$.

All samples were divided into two groups according to the type of ceramic:

- Group $(n=20)$ Z: ZLS ceramics (Celtra due, Dentsply-Sirona, Bensheim, Germany).

- $\quad$ Group $(n=20)$ L: Lithium disilicate ceramics (IPS E.MAX, Ivoclar Vivadent AG, Schaan, Liechtenstein, USA).

Each group was subdivided into two subgroups $(n=10)$, according to the aging procedure:

- $\quad$ Subgroup - ZA: Aging.

- $\quad$ Subgroup - ZB: No aging.

- $\quad$ Subgroup - LA: Aging.

- $\quad$ Subgroup - LB: No aging.

The second premolar tooth was collected from the orthodontic department with average size and free of caries or cracks. For disinfection purposes, teeth were immersed in a $5.25 \%$ sodium hypochlorite solution for $24 \mathrm{~h}$. Thereafter, they were stored in saline.

The second premolar tooth was used in this study and was prepared with a deep chamfer finish line for complete crowns. Tooth preparations were done by one operator with a total convergence angle of $10-12^{\circ}$, chamfer margins of $30^{\circ}$ circumferentially, $1 \mathrm{~mm}$ circumferential, and occlusal reduction of $1.5 \mathrm{~mm}$. All line angles were rounded (Figure 1).

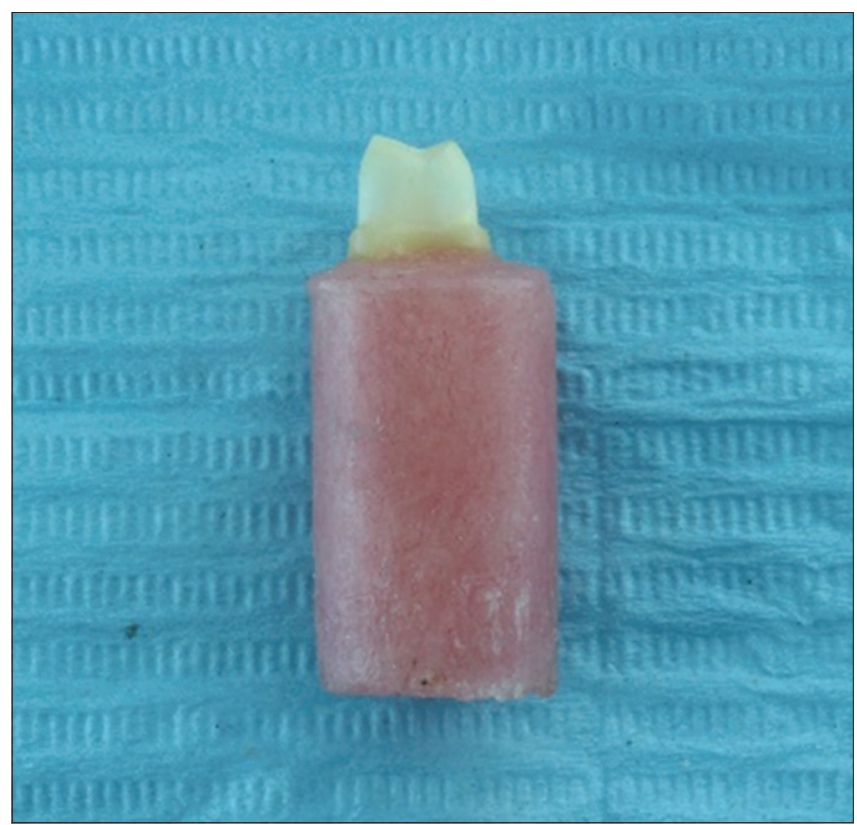

Figure 1: Prepared maxillary second premolar tooth

Then, the prepared tooth was embedded in an acrylic resin (Acrostone, Egypt) base to create a model.

Special trays were made from acrylic resin (Figure 2) to take an impression for the model to make 40 models from the prepared tooth and the impressions

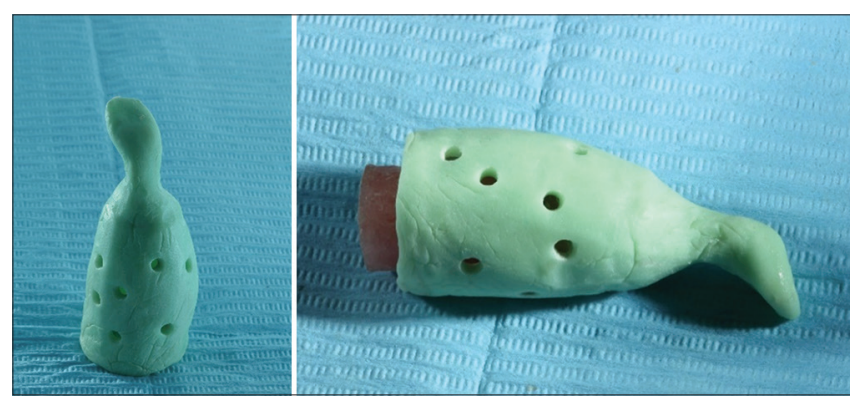

Figure 2: Acrylic special tray

were taken by polyether impression material (3M ESPE Monophase Polyether Impression Material, 3M/ESPE, AG, Seefeld, Germany).

Epoxy resin (Kemapoxy 150, CMB international, Giza, Egypt) was used to pour all impressions to make the models of the prepared tooth (Figure 3).

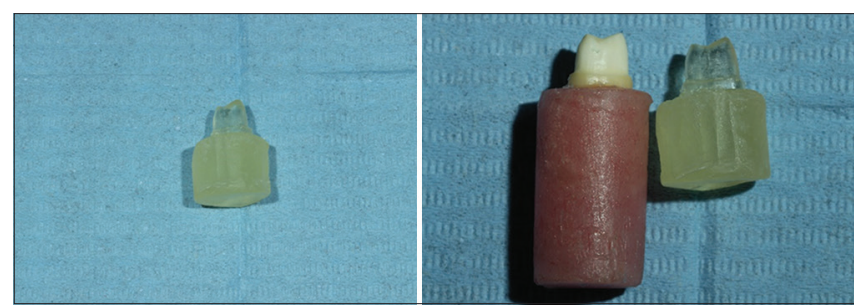

Figure 3: Epoxy model

Then, the digital impression (Figure 4) was taken by CEREC Omnicom (Dentsply-Sirona, Bensheim, Germany) for the prepared tooth.

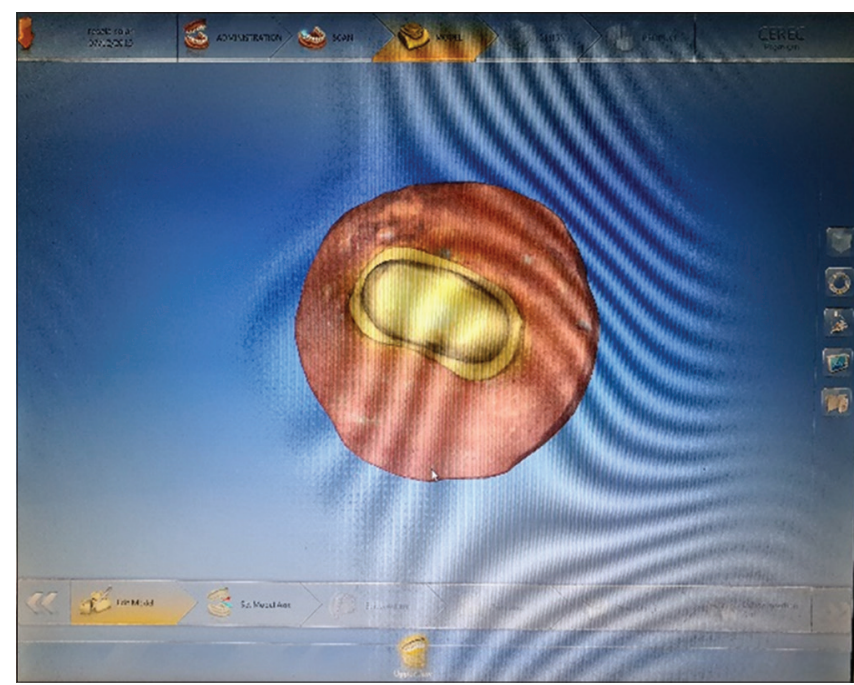

Figure 4: Digital impression

The same design of the prepared tooth made by CEREC premium software (Dentsply-Sirona, Bensheim, Germany) (Figure 5).
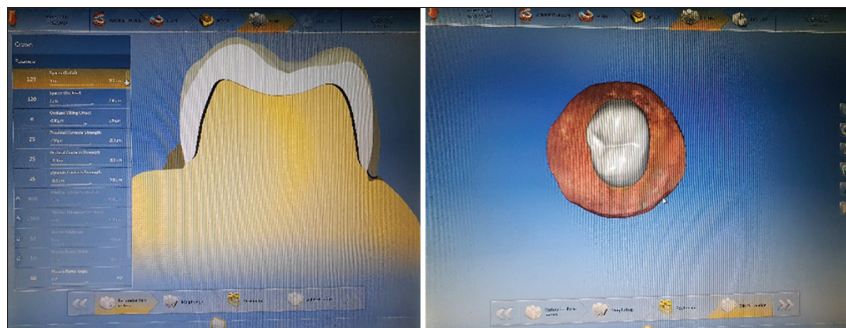

Figure 5: Crown designing 
Both ceramics had the same parameters; spacer radial and occlusal were $120 \mu$, the marginal Ramp angle was 600 , minimum thickness radial was $800 \mu$, minimum thickness occlusal was $1000 \mu$, margin thickness was $50 \mu$, and the marginal ramp width was $50 \mu$ (Figure 5).

Crowns milling (Figure 6) made using CEREC MCXL (Dentsply-Sirona, Bensheim, Germany) for ceramic blocks (C14), and the sprue was placed toward the palatal surface.
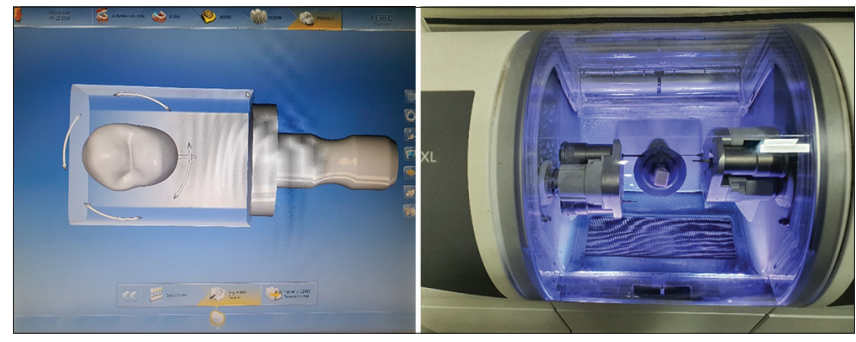

Figure 6: Crowns milling

After milling the crowns cleaned with a steam cleaner carefully blow-dry the restoration in an airstream then try into examine its fit. Sprue removal was done using a grinding instrument. Before glazing the surface cleaned with a steam cleaner.

Using IPS E.MAX CAD glaze (Ivoclar Vivadent AG, Schaan, Liechtenstein, USA ) and was applied to the entire crown surface using a brush and then inserted into ceramic furnace programat P310 (Ivoclar Vivadent AG, Schaan, Liechtenstein, USA) (Figure 7).
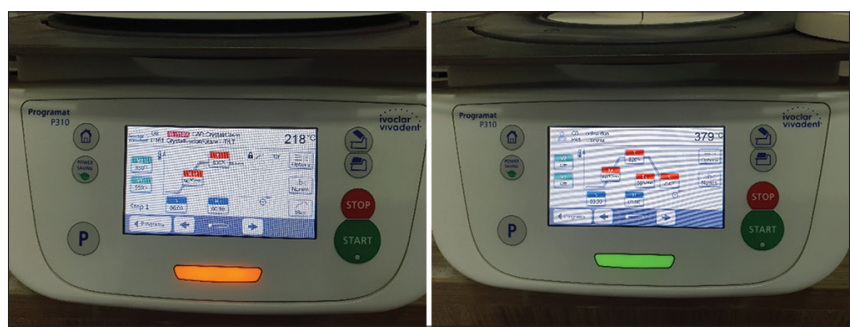

Figure 7: Crystallization and glazing

- $\quad$ Celtra due firing program was (Table 1):

- $\quad$ IPS E-MAX firing program is Table 2:

Before cementation with the adhesive resin, the fitting surfaces of the crowns were cleaned using $36 \%$ phosphoric acid etching gel, followed by etching with $9.5 \%$ hydrofluoric acid gel (porcelain etchant) (Bisco, Schaumburg, USA) for the $20 \mathrm{~s}$. Then, the etched ceramic surface was cleaned using water spray for the 60s. A silane coupling agent (porcelain primer) (Bisco, Schaumburg, USA) was applied to the inner surface of each crown immediately and air-dried in the $60 \mathrm{~s}$. Then, the ceramic crowns were cemented to epoxy teeth using the adhesive resin cement (BIS Cem) (Bisco, Schaumburg, USA). The excess cement at the margin was removed carefully, and an air-inhibiting gel was applied. The composite resin cement was lightly cured Blue $\mathrm{N}$ phase (Ivoclar Vivadent AG, Schaan, Liechtenstein, USA) for the $30 \mathrm{~s}$ on each side with a light intensity of $1200 \mathrm{~mW} / \mathrm{cm}^{2}$ (Figure 8 ).

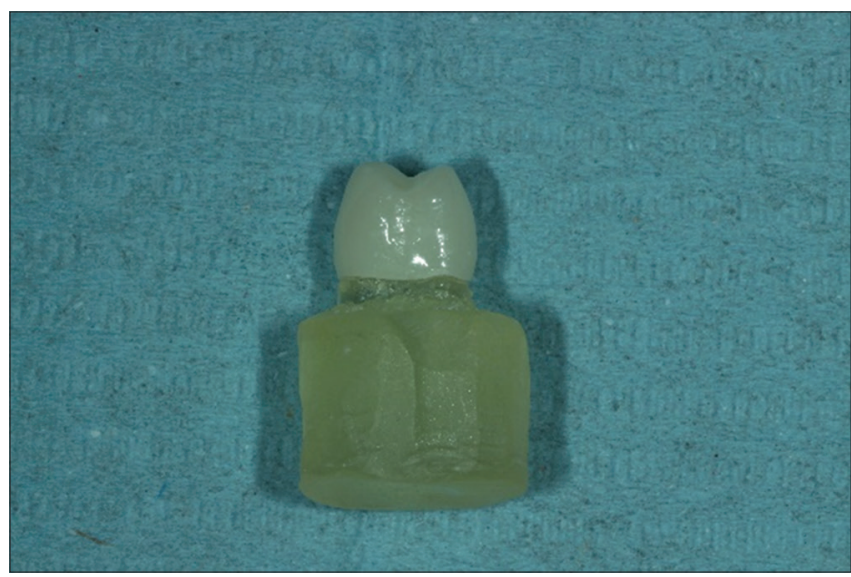

Figure 8: Cemented crown

After crowns cementation, both subgroups ZA and LA were subjected to the aging procedure.

The samples were first washed 3 times with ethyl alcohol then dried then immersed into a $4 \%$ acetic acid solution at a temperature of $800^{\circ} \mathrm{C}$ and kept for $16 \mathrm{~h}$ according to the ISO standards for hydrolytic resistance of dental ceramic materials (ISO 6872) [7] . After cooling at room temperature at the end of the test the samples will be removed, rinsed with de-ionized distilled water and ethyl alcohol, and dried.

Then, the samples were placed in a universal test machine (Instron) for the fracture resistance test. A stainless-steel ball $3 \mathrm{~mm}$ diameter was used to apply a compressive load on the occlusal surface along the long axis of the tooth at a crosshead speed of $1 \mathrm{~mm}$ $\mathrm{min}$. This compressive load was centered on the midline at the central fossa of each crown (Figure 9). A piece of polyethylene foil, with $1 \mathrm{~mm}$ thickness, was placed between the crown and the ball to achieve a uniform

Table 1: Celtra due firing program

\begin{tabular}{|c|c|c|c|c|c|c|c|}
\hline $\begin{array}{l}\text { Standby Temperature } \\
\text { B }\end{array}$ & $\begin{array}{l}\text { Closing time } \\
\mathrm{S}\end{array}$ & $\begin{array}{l}\text { Heating rate } \\
\eta\end{array}$ & $\begin{array}{l}\text { Firing temperature } \\
T\end{array}$ & $\begin{array}{l}\text { Holding time } \\
\text { H }\end{array}$ & $\begin{array}{l}\text { Vacuum } \\
\text { on/off }\end{array}$ & $\begin{array}{l}\text { Long-term Cooling } \\
\text { L }\end{array}$ & $\begin{array}{l}\text { Cooling temperature } \\
\mathrm{tL}\end{array}$ \\
\hline${ }^{\circ} \mathrm{C}$ & $\min$ & ${ }^{\circ} \mathrm{C} / \mathrm{min}$ & ${ }^{\circ} \mathrm{C}$ & $\min$ & $\begin{array}{l}\operatorname{Vac} 1\left({ }^{\circ} \mathrm{C}\right) \\
\operatorname{Vac} 2\left({ }^{\circ} \mathrm{C}\right)\end{array}$ & ${ }^{\circ} \mathrm{C}$ & ${ }^{\circ} \mathrm{C}$ \\
\hline 500 & 3:30 & 60 & 820 & 1:00 & off & 750 & 50 \\
\hline
\end{tabular}

Table 2: IPS E-MAX firing program

\begin{tabular}{|c|c|c|c|c|c|c|c|c|c|c|c|}
\hline $\begin{array}{l}\text { Stand-by temperature } \\
\mathrm{B}\left[{ }^{\circ} \mathrm{C} /{ }^{\circ} \mathrm{F}\right]\end{array}$ & $\begin{array}{l}\text { Closing time } \\
\mathrm{S} \text { [min] }\end{array}$ & $\begin{array}{l}\text { Heating rate } \\
\mathrm{t} 1\left[^{\circ} \mathrm{C} /{ }^{\circ} \mathrm{F} / \mathrm{min}\right]\end{array}$ & $\begin{array}{l}\text { Firing temperature } \\
\mathrm{T} 1\left[{ }^{\circ} \mathrm{C} /{ }^{\circ} \mathrm{F}\right]\end{array}$ & $\begin{array}{l}\text { Holding } \\
\text { time } \\
\text { H1 [min] }\end{array}$ & $\begin{array}{l}\text { Heating rate } \\
\mathrm{t} 2\left[{ }^{\circ} \mathrm{C} /{ }^{\circ} \mathrm{F} / \mathrm{min}\right]\end{array}$ & $\begin{array}{l}\text { Firing } \\
\text { temperature } \\
\mathrm{T} 2\left[{ }^{\circ} \mathrm{C} /{ }^{\circ} \mathrm{F}\right]\end{array}$ & $\begin{array}{l}\text { Holding } \\
\text { time } \\
\text { H2 [min] }\end{array}$ & $\begin{array}{l}\text { Vacuum } 1 \\
11\left[{ }^{\circ} \mathrm{C} /{ }^{\circ} \mathrm{F}\right] \\
12\left[{ }^{\circ} \mathrm{C} /{ }^{\circ} \mathrm{F}\right]\end{array}$ & $\begin{array}{l}\text { Vacuum } 2 \\
21\left[{ }^{\circ} \mathrm{C} /{ }^{\circ} \mathrm{F}\right] \\
22\left[{ }^{\circ} \mathrm{C} /{ }^{\circ} \mathrm{F}\right]\end{array}$ & $\begin{array}{l}\text { Long-term } \\
\text { cooling } \mathrm{L} \\
{\left[{ }^{\circ} \mathrm{C} /{ }^{\circ} \mathrm{F}\right]}\end{array}$ & $\begin{array}{l}\text { Cooling rate } \\
\mathrm{tl}\left[{ }^{\circ} \mathrm{C} /{ }^{\circ} \mathrm{Fmin}\right]\end{array}$ \\
\hline $403 / 757$ & $0: 30$ & 120/216 & $850 / 1562$ & $0: 00$ & $70 / 126$ & $870 / 1598$ & $3: 30$ & $\begin{array}{l}690 / 850 \\
1274 / 1562 \\
\end{array}$ & $\begin{array}{l}850 / 870 \\
1562 / 1598\end{array}$ & $705 / 1301$ & 0 \\
\hline
\end{tabular}



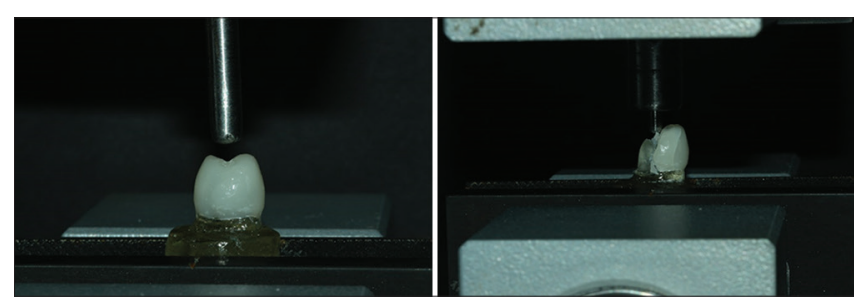

Figure 9: Fracture resistance test

distribution of the force [8]. The maximum load at which the specimens fractured was recorded in Newton's.

Statistical analysis was done using one-way ANOVA and Multiple Comparisons. Dependent Variable: VAR00002 LSD.

\section{Results}

Means and standard deviations of the fracture resistance of the ZLS before aging and ZLS after aging are shown in Table 3 . The results showed that there

Table 3: Fracture resistances of zirconia-reinforced lithium silicates before and after aging in $\mathbf{N}$

\begin{tabular}{lll}
\hline Groups & Mean & Standard deviation \\
\hline Zirconia-reinforced lithium silicates before aging & 1093.96 & 120.01 \\
Zirconia-reinforced lithium silicates after aging & 877.07 & 94.62 \\
\hline
\end{tabular}

is a statistically significant difference between the two groups. ZLS before aging recorded higher fracture resistance $(1093.96 \mathrm{~N})$ than ZLS after aging $(877.07 \mathrm{~N})$ (Figure 10).

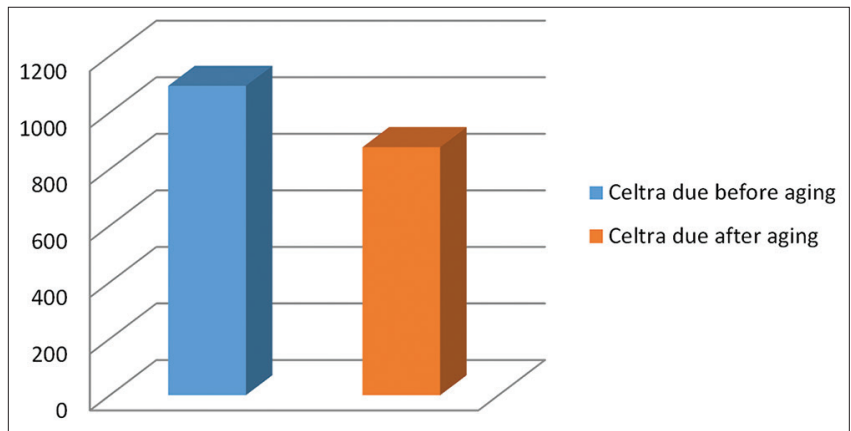

Figure 10: A comparison between fracture resistances of zirconiareinforced lithium silicates without and with aging

Means and standard deviations of the fracture resistance of the lithium disilicate before aging and lithium disilicate after aging are shown in the Table 4. The results showed that there is a statistically significant difference between the two groups. Lithium disilicate before aging recorded higher fracture resistance $(1052.16 \mathrm{~N})$ than after aging (862.7N) (Figure 11).

Table 4: Fracture resistances of lithium disilicate before and after aging in $\mathbf{N}$

\begin{tabular}{lll}
\hline Groups & Mean & Standard deviation \\
\hline Lithium disilicate before aging & 1052.16 & 282.29 \\
Lithium disilicate after aging & 862.7 & 184.6 \\
\hline
\end{tabular}

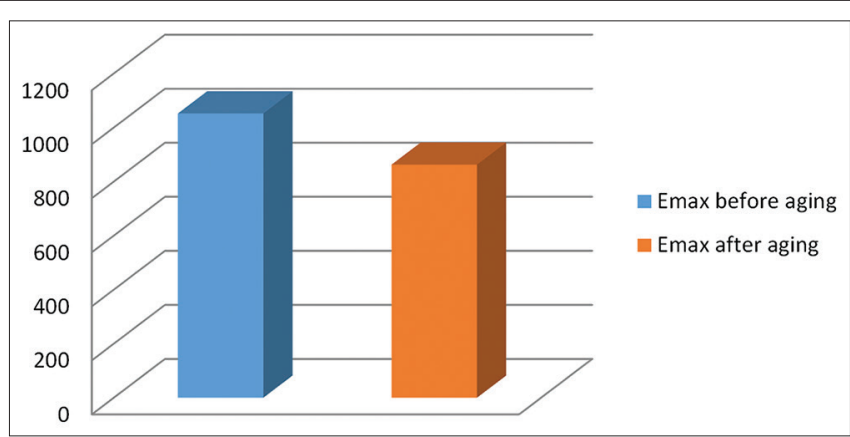

Figure 11: A comparison between fracture resistances of lithium disilicate without and with aging

Figure 12 showed a comparison between the two tested ceramics before and after aging, although that ZLS recorded higher fracture resistance than lithium disilicate before and after aging (1093.96\# 1052.16) and (877.07\# 862.7), there was no statistically significant difference between these two ceramics.

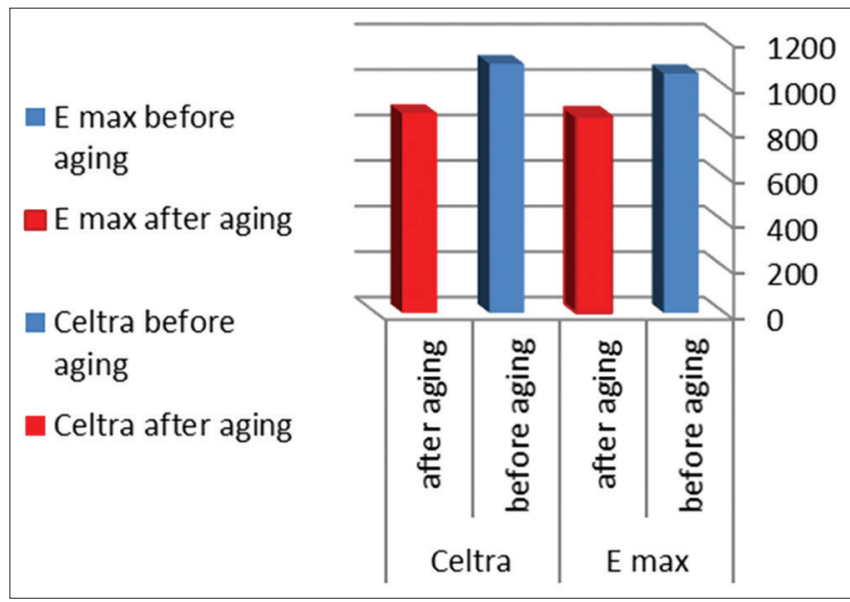

Figure 12: A comparison between fracture resistances of all groups

\section{Discussion}

This study evaluated and compared the fracture resistance of ZLS with the lithium silicate CAD/ CAM crowns.

In the present study, the materials tests were conducted to evaluate the mechanical properties of both CAD/CAM ceramic materials under standardized conditions.

Crowns' designs were manufactured by CAD/ CAM; they had the same design and parameters.

Fracture resistance is the nominal property of a material when this is resisting the development of a fracture. Hence, fracture resistance tests of ceramic materials are essential for the anticipated lifetime with an adequate low possibility of failure [9].

In this study, the fracture resistance of ZLS is higher than lithium disilicate due to homogeneous fine 
crystalline structure in zirconia lithium silicate while lithium disilicate revealed a structure with needleshaped fine-grained crystals embedded in a glassy matrix. The ZLS revealed a lower probability of failure and a higher strength than lithium disilicate according to Weibull Analysis [10]. Although, this difference in fracture resistance was not statistically significant.

Half of the crowns were subjected to an aging procedure according to ISO 6872 [7]

The acidic acid used caused rough surfaces to the ceramics tested. In the oral cavity, the ceramic restorative materials would be exposed to the various temperature and acidic-base changes from food and beverages. Hence, the ceramic materials should resist or have only little changes in these environments. The previous studies have reported a clinical service life of metal-ceramic restorations up to 20 years [11], [12].

Acetic acid is the acid used for chemical stability testing following ISO standard 6872 [7], and affected the fracture resistance of both ceramics and lowers the fracture resistance.

The previous studies have documented that increasing surface roughness of ceramics may decrease strength [13], [14]. The increasing surface roughness of the studied ceramics may cause bacterial colonization, strength reduction of the ceramics evaluated, and would result in clinical failure of ceramic restorations [15].

Acetic acid is a weak organic acid; however, it is fairly corrosive to ceramics because of its chelating effect [16].

\section{Conclusion}

The fracture resistance of ZLS is higher than lithium disilicate without aging.

The groups subjected to aging showed lower fracture resistance than that not subjected.

\section{References}

1. Culp L, McLaren EA. Lithium disilicate: The restorative material of multiple options. Compend Contin Educ Dent. 2010;31(9):716-20 PMid:21197940

2. Tinschert J, Natt G, Mautsch W, Augthun M, Spiekermann H. Fracture resistance of lithium disilicate--, alumina-, and zirconiabased three-unit fixed partial dentures: A laboratory study. Int J Prosthod. 2001;14(3):231-8. https://doi.org/10.4047/ jap.2017.9.4.244

\section{PMid: 11484570}

3. Nawafleh N, Hatamleh M, Elshiyab S, Mack F. Lithium disilicate restorations fatigue testing parameters: A systematic review. J Prosthod. 2016;25(2):116-26. https://doi.org/10.1111/jopr.12376 PMid:26505638

4. Kelly JR. Clinically relevant approach to failure testing of allceramic restorations. J Prosthet Dent. 1999;81(6):652-61. https://doi.org/10.1016/s0022-3913(99)70103-4 PMid:10347352

5. Zhang Y, Kim JW, Bhowmick S, Thompson VP, Rekow ED. Competition of fracture mechanisms in monolithic dental ceramics: Flat model systems. J Biomed Mater Res Part B. 2009;88(2):402-11. https://doi.org/10.1002/jbm.b.31100 PMid: 18478533

6. Guess PC, Schultheis S, Bonfante EA, Coelho PG, Ferencz JL, Silva NR. All-ceramic systems: Laboratory and clinical performance. Dent Clin. 2011;55(2):333-52. https://doi. org/10.1016/j.cden.2011.01.005

PMid:21473997

7. International Organization for Standardization. International Organization for Standardization No. 6872, Dentistry-ceramic Materials. Geneva, Switzerland: International Organization for Standardization; 2008.

8. Sun T, Zhou S, Lai R, Liu R, Ma S, Zhou Z, et al. Loadbearing capacity and the recommended thickness of dental monolithic zirconia single crowns. J Mech Behav Biomed Mater 2014;35:93-101.j https://doi.org/10.1016/j.jmbbm.2014.03.014 PMid:24762856

9. Ritter JE. Predicting lifetimes of materials and material structures. Dent Mater. 1995;11(2):142-6. https://doi. org/10.1016/0109-5641(95)80050-6 PMid:8621036

10. Elsaka SE, Elnaghy AM. Mechanical properties of zirconia reinforced lithium silicate glass-ceramic. Dent Mater. 2016;32(7):908-14. https://doi.org/10.1016/j.dental.2016.03.013 PMid:270876

11. De Backer H, Van Maele G, De Moor N, Van den Berghe L, De Boever J. A 20-year retrospective survival study of fixed partial dentures. Int J Prosthod. 2006;19(2):143-53.

PMid:16602362

12. Näpänkangas R, Raustia A. Twenty-year follow-up of metalceramic single crowns: A retrospective study. Int J Prosthod. 2008;21(4):307-11. https://doi.org/10.1111/j.1365-2842.1997. tb00266.x PMid: 18717088

13. Clayton JA, Green E. Roughness of pontic materials and dental plaque. J Prosthet Dent. 1970;23(4):407-11. https://doi. org/10.1016/0022-3913(70)90007-7 PMid:5264825

14. De Jager N, Feilzer AJ, Davidson CL. The influence of surface roughness on porcelain strength. Dent Mater. 2000;16(6):381-8. https://doi.org/10.1016/s0109-5641(00)00030-0 PMid:10967186

15. Bollenl CM, Lambrechts $P$, Quirynen M. Comparison of surface roughness of oral hard materials to the threshold surface roughness for bacterial plaque retention: A review of the literature. Dent Mater. 1997;13(4):258-69. https://doi. org/10.1016/s0109-5641(97)80038-33 PMid:11696906

16. Milleding $\mathrm{P}$, Haraldsson $\mathrm{C}$, Karlsson $\mathrm{S}$. Ion leaching from denta ceramics during static in vitro corrosion testing. J Biomed Mater Res. 2002;61(4):541-50. https://doi.org/10.1002/jbm.10109 PMid:12115444 